\title{
pH-Responsive Artesunate Polymer Prodrugs with Enhanced Ablation Effect on Rodent Xenograft Colon Cancer [Corrigendum]
}

Hao DL, Xie R, De GJ, et al. Int J Nanomed. 2020;15:1771-1786.

The authors have advised due to an error that occurred inadvertently at the time of figure assembly, the images of the cellular uptake of free $\mathrm{C}_{6}$ and ART-M1- $\mathrm{C}_{6}$ are incorrect for Figure 1 on page 1780.

The correct Figure 1 is shown below.

A

DAPI

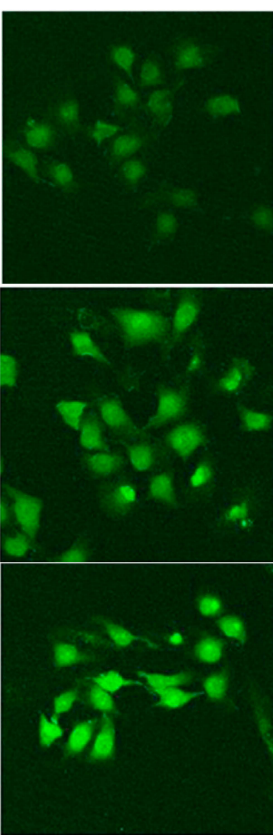

Merge
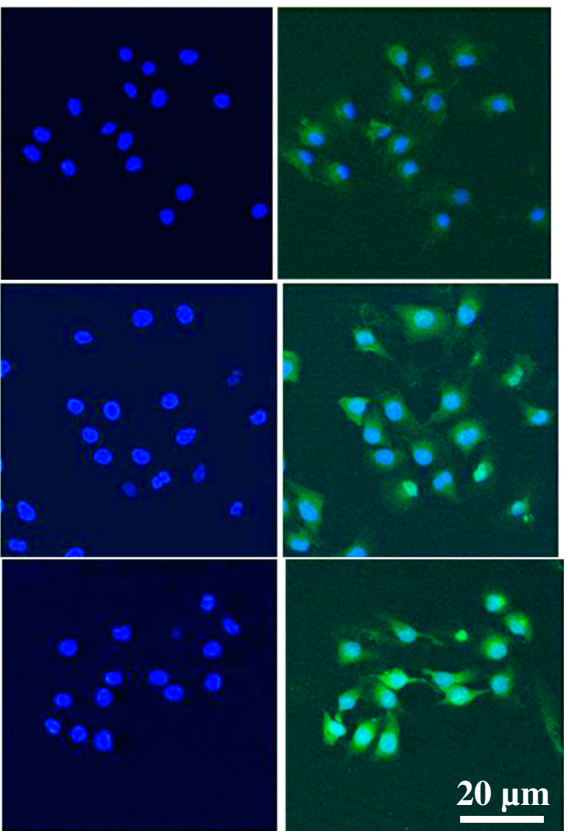

B

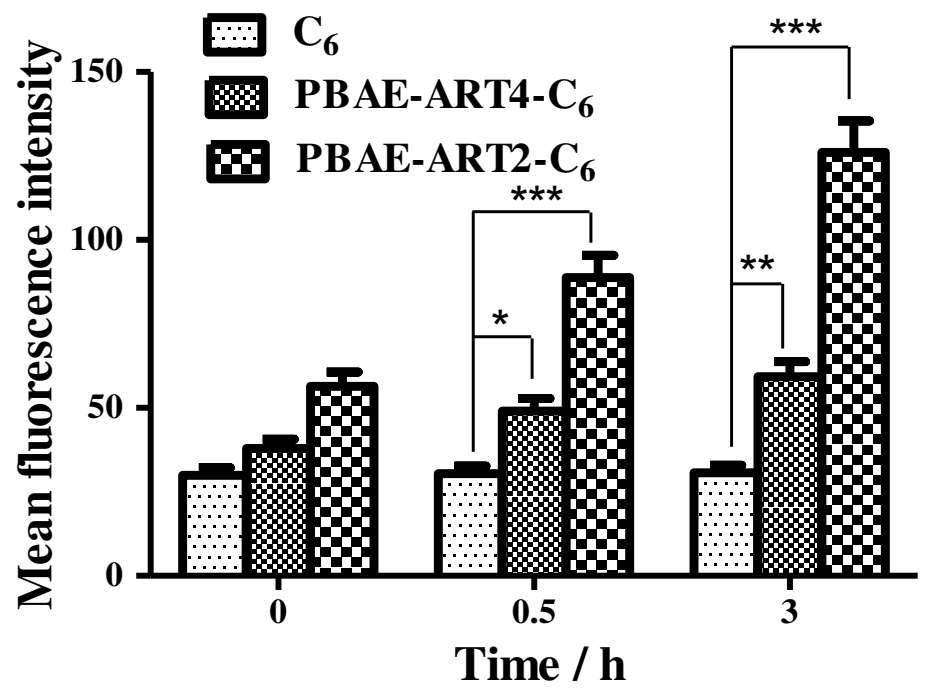

Figure I Cellular uptake of free $\mathrm{C}_{6}$ and micelles incorporated $\mathrm{C}_{6}$. (A) Confocal FL images of cellular internalized $\mathrm{C}_{6}$, PBAE-ART4- $\mathrm{C}_{6}$ and PBAE-ART2- $\mathrm{C}_{6}$, after $3 \mathrm{~h}$ incubation with CT-26 cells. Blue FL represents DAPI, green FL represents $\mathrm{C}_{6}$. (B) Flow cytometry analysis of mean $\mathrm{FL}$ intensity ( $\mathrm{n}=10,000$ cells) in CT-26 cells incubated with $\mathrm{C}_{6}$, PBAE-ART4- $\mathrm{C}_{6}$ and PBAE-ART2- $\mathrm{C}_{6}$ for $0.5 \mathrm{~h}$ and $3 \mathrm{~h}$, respectively. Data are presented as the mean of three measurements \pm SD. $* P<0.05$, $* * P<0.0 \mathrm{I}$, $* * * P<0.00 \mathrm{I}$. 
The authors have also advised on page 1779, Cytotoxicity Assay and Cellular Apoptosis Analysis section, second paragraph, the text "The apoptosis rates for cells treated with free ART, PBAE-ART4 and PBAE-ART2 for $24 \mathrm{~h}$ were $8.76 \%$, $11.88 \%$ and $14.27 \%$, respectively. After incubation for $72 \mathrm{~h}$, the apoptosis rates were increased to $18.41 \%, 22.49 \%$ and $26.85 \%$, respectively, with stronger apoptosis rates were observed in the micelles groups than that of free drug (Figure 2)" should read "The apoptosis rates for cells treated with free ART, PBAE-ART4 and PBAE-ART2 for $24 \mathrm{~h}$ were $8.73 \%, 11.84 \%$ and $14.23 \%$, respectively. After incubation for $72 \mathrm{~h}$, the apoptosis rates were increased to $18.35 \%$, $22.42 \%$ and $26.76 \%$, respectively, with stronger apoptosis rates were observed in the micelles groups than that of free drug (Figure 2)."

The authors also advised that there is an error in Figure S2 of the supplementary material, the images of the CMC of PEOz-PLA-PBAE-2 and PEOz-PLA-PBAE-3 should be interchanged.

The correct Figure S2 is shown below.

The authors apologize for these errors and advise they do not affect the results and conclusions of the paper.

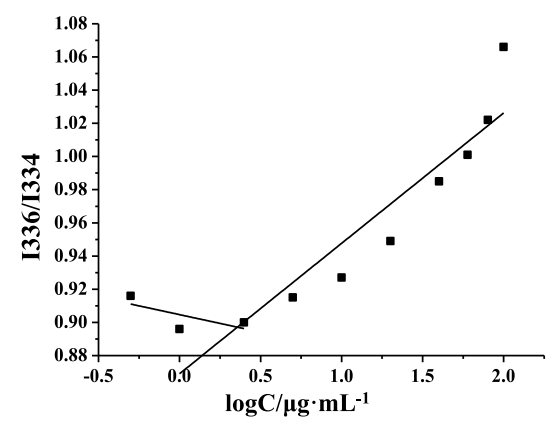

PEOz-PLA-PBAE-1

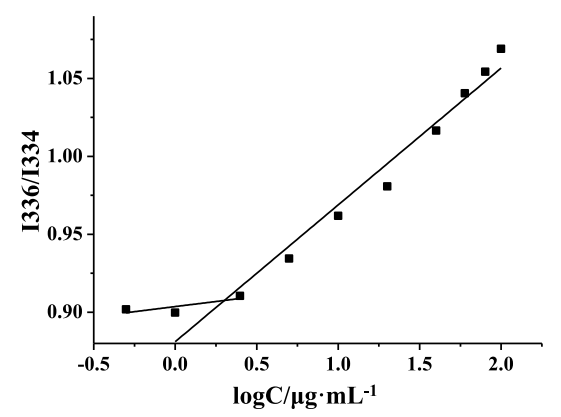

PEOz-PLA-PBAE-4

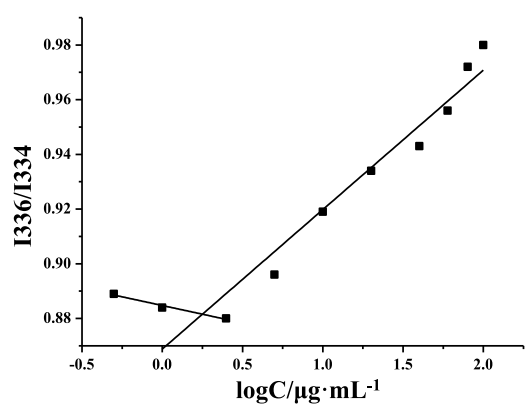

PEOz-PLA-PBAE-2

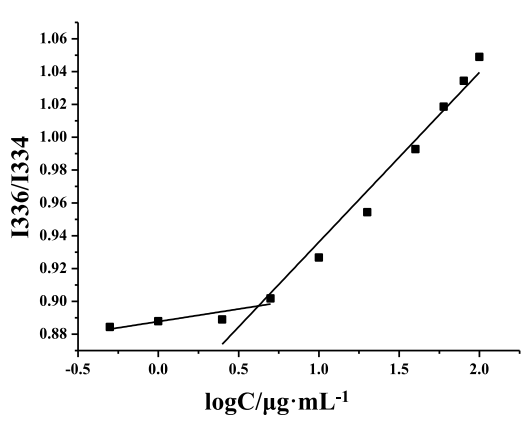

PEOz-PLA-PBAE-5

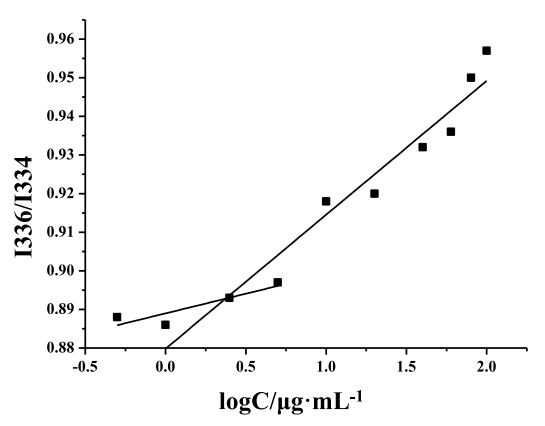

PEOz-PLA-PBAE-3

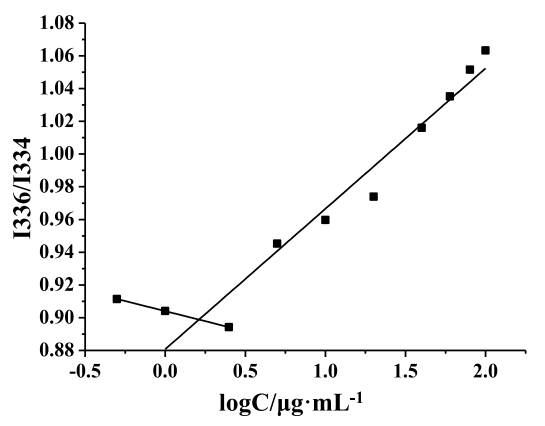

PEOz-PLA-PBAE-6

Figure S2 The CMC values of the PEOz-PLA-PBAEs copolymer micelles.

\section{Publish your work in this journal}

The International Journal of Nanomedicine is an international, peerreviewed journal focusing on the application of nanotechnology in diagnostics, therapeutics, and drug delivery systems throughout the biomedical field. This journal is indexed on PubMed Central, MedLine, CAS, SciSearch ${ }^{\mathbb{R}}$, Current Contents ${ }^{\mathbb{R}} /$ Clinical Medicine,
Journal Citation Reports/Science Edition, EMBase, Scopus and the Elsevier Bibliographic databases. The manuscript management system is completely online and includes a very quick and fair peer-review system, which is all easy to use. Visit http://www.dovepress.com/ testimonials.php to read real quotes from published authors. 